\title{
Morphometry and retention time as forcing functions to establishment and maintenance of aquatic macrophytes in a tropical reservoir
}

\author{
M. B. Cunha-Santino ${ }^{a, b *}$, A. T. Fushita ${ }^{a}$, A. C. Peret Peb $^{a, b}$ and I. Bianchini-Junior ${ }^{a, b}$ \\ ${ }^{a}$ Departamento de Hidrobiologia, Universidade Federal de São Carlos - UFSCar, Rodovia Washington Luiz, \\ Km 235, CP 676, CEP 13565-905, São Carlos, SP, Brazil \\ 'Programa de Pós-graduação em Ecologia e Recursos Naturais, Universidade Federal de São Carlos - UFSCar, \\ Rodovia Washington Luiz, Km 235, CP 676, CEP 13565-905, São Carlos, SP, Brazil \\ *e-mail: cunha_santino@ufscar.br
}

Received: November 24, 2014 - Accepted: April 30, 2015 - Distributed: August 31, 2016

(With 6 figures)

\begin{abstract}
Macrophytes may constitute an important resource for several chemical, physical and biological processes within aquatic ecosystems. This study considers that in tropical reservoirs with low retention time and with low values of shoreline development $\left(\mathrm{D}_{\mathrm{L}}\right)$, the expansion and persistence of aquatic macrophytes are mainly reported to local conditions (e.g., hydrodynamic and wind exposure) rather than trophic status and depth of the euphotic zone. In this context, this study aimed at describing and comparing the incidence of aquatic macrophytes in a throughflowing, non-dendritic tropical reservoir. During February 2006 to November 2007, eight limnological surveys were performed quarterly within the Ourinhos Reservoir, and in the mouth areas of its tributaries. At the six sampling stations 30 variables were measured. The number of sites with plants varied between 21 and 38 and at the end of the $1^{\text {st }}$ year the total richness was found. The sampling survey outcome the recognition of 18 species of aquatic macrophytes; Cyperaceae (2 genera and 1 species), Pontederiaceae (3 species) and Onarograceae (3 genera) were the families with higher diversity. Seven species (Typha domingensis Pers., Myriophyllum aquaticum (Vell.) Verdec, Salvinia auriculata Aubl., Eichhornia azurea (Sw.) Kunth, Eleocharis sp1, Eichhornia crassipes (Mart.) Solms, Oxycaryum cubense (Poepp. \& Kunth) Lye) always were present and were more frequent in the sites. The occurrence of emergent species predominated $(45.9 \%)$, followed by submersed rooted (24.5\%), free floating (19.5\%), floating rooted (9.7\%) and free submersed $(0.3 \%)$. Although limnological variables and the distribution of macrophytes have discriminated the same sampling points, the stepwise multiple linear regressions did not pointed out strong correspondences (or coherence) among the most constant and distributed macrophyte species and the selected limnological variables, as well the trophic statuses. Seeing the low relationship among limnological variables and macrophytes distribution, in the case of Ourinhos Reservoir, the results pointed out that the water turbulence, low $\mathrm{D}_{\mathrm{L}}$ and wind exposure are the main driving forces that determine its aquatic plant distribution, life forms and species composition.
\end{abstract}

Keywords: aquatic plants, biodiversity, population dynamic, drive functions, limnological constrains, Paranapanema River, Ourinhos HPP.

\section{Morfometria e tempo de residência como fatores determinantes no estabelecimento e manutenção de macrófitas aquáticas em um reservatório tropical}

\section{Resumo}

As macrófitas podem constituir um recurso importante para vários processos físicos, químicos e biológicos dos ecossistemas aquáticos. Esse estudo considera que nos reservatórios tropicais com baixo tempo de retenção e com baixos valores do grau de desenvolvimento das margens $\left(\mathrm{D}_{\mathrm{L}}\right)$, a expansão e manutenção das macrófitas aquáticas são referidas principalmente às condições locais (e.g., hidrodinâmica e exposição ao vento), ao invés do estado trófico e da profundidade de zona eufótica. Nesse contexto, o presente estudo teve como objetivo descrever e comparar a incidência de macrófitas aquáticas em um reservatório tropical de fluxo rápido e não dendrítico. De fevereiro de 2006 a novembro de 2007, oito avaliações limnológicas foram realizadas trimestralmente no reservatório Ourinhos e nas regiões de desembocadura de seus afluentes. Nas seis estações de amostragem 30 variáveis foram determinadas. O número de locais com plantas variou entre 21 e 38 e no final do primeiro ano o número total de espécies foi encontrado. Foram relacionadas 18 espécies de macrófitas aquáticas; Cyperaceae ( 2 gêneros e espécies), Pontederiaceae (3 espécies) e Onarograceae (3 gêneros) foram as famílias com mais diversidade. Sete espécies (Typha domingensis 
Pers., Myriophyllum aquaticum (Vell.) Verdec, Salvinia auriculata Aubl., Eichhornia azurea (Sw.) Kunth, Eleocharis sp1, Eichhornia crassipes (Mart.) Solms, Oxycaryum cubense (Poepp. \& Kunth) Lye) sempre estiveram presentes e foram as mais frequentes. As ocorrências de espécies emergentes predominaram (45,9\%), seguidas das submersas enraizadas (24,5\%), flutuantes livres (19,5\%), flutuantes enraizadas $(9,7 \%)$ e submersas livres $(0,3 \%)$. Embora as variáveis limnológicas e as distribuições de macrófitas tenham discriminado os mesmo pontos de coleta, regressões lineares múltiplas stepwise não apontaram correspondências fortes (ou coerentes) entre as espécies de macrófitas mais constantes e distribuídas e as variáveis limnológicas, assim como os estados tróficos. No reservatório Ourinhos, a baixa relação entre as variáveis limnológicas e a distribuição das macrófitas aponta que a turbulência da água, o baixo valor de $\mathrm{D}_{\mathrm{L}}$ e a exposição ao vento sejam as principais forças que determinam a distribuição das plantas aquáticas, as suas formas de vida e a composição das espécies.

Palavras-chave: plantas aquáticas, biodiversidade, dinâmica de população, funções de força, condicionantes limnológicas, rio Paranapanema, UHE Ourinhos.

\section{Introduction}

Neotropical aquatic ecosystems usually support several species of aquatic macrophytes (Neiff et al., 2008; Rolon et al., 2010; Piedade et al., 2010). The metabolic response of these organisms to abiotic factors combined with biological interactions (e.g., competition for light, herbivory, allelopathy) determine the basis of the community diversity and abundance (Lacoul and Freedman, 2006; Bornette and Puijalon, 2009).

The high ability of macrophytes to explore distinct compartments (water column and sediment) within a aquatic systems is reflected by different life forms such as emergent, submersed and floating plants (Riemer, 1984), and for encompass diverse types of plants, macrophytes are included in different plant divisions: algae, bryophytes and vascular plants (Chambers et al., 2008). Thus, the macrophytes are key resources to habitat structuring, and in supporting the trophic chains and several chemical, physical and biological processes within aquatic ecosystems (Thomaz and Cunha, 2010).

Reservoirs consistently differ from natural ecosystems due to geomorphologic changes resulting from their formation facilitating macrophyte establishment (Havel et al., 2005). After damming, lotic systems are subject to relative stabilization of water levels generating habitats suitable for macrophytes community expansion (Thomaz et al., 2009a). The increase of underwater radiation after transformation a river into a reservoir is an additional alteration that favors the development of submersed species (Agostinho et al., 1999; Figueiredo and Bianchini Junior, 2008). Free-floating macrophytes (e.g., Eicchornia crassipes, Pistia stratiotes and Salvinia spp) are most common in several Neotropical man-made-lakes, but submersed and emergent species also occur frequently, for instance: Egeria najas, Egeria densa, Utricularia ssp, Cabomba furcata, Najas sp, Eichhornia azurea, Eleocharis ssp, Ludwigia spp, Oxycaryum cubense, Echinochloa polystachya and Typha domingensis (Vilarrubia and Cova, 1993; Bini et al., 1999; Pompêo et al., 2001; Tanaka et al., 2002; Marcondes et al., 2003; Bini et al., 2005; Thomaz et al., 2006, 2009a, 2009b; Martins et al., 2008; Bianchini Junior et al., 2010).

Aquatic macrophytes are affected by spatial and temporal scales, which may drive their successful establishment and development (Ferreira et al., 2015); the changes in species composition between habitat patches are related to a number of factors, including environmental heterogeneity, connectivity, disturbance and productivity (Partanen et al., 2009; Lopes et al., 2014). A number of explanations have been raised to account for the high proportion of widely distributed taxa among the aquatic plants. They include: i) the uniformity of aquatic environment; ii) widespread clonality; iii) high phenotypic plasticity (Santamaria, 2002). Furthermore, according to the bottom-up control concept (Glibert, 1998), the growth and establishment of aquatic plants are associated with physical and chemical factors such as: temperature, underwater radiation, nutrients availability, sediment composition, littoral slope, water speed, waves, wind exposure (Carr et al., 1997; Hudon et al., 2000).

Aquatic plants integrate temporal, spatial, chemical, physical and biological characteristics of an ecosystem, and their spreading and richness are influenced by changes in environmental conditions (Lacoul and Freedman, 2006). Taking into account the many factors that contribute to the establishment of aquatic plants, this study considered the following hypothesis: in a tropical reservoir with low retention time (i.e., RT < two weeks; Straškraba, 1999) and with low values of shoreline development $\left(D_{L}\right)$, the expansion and maintenance of aquatic macrophytes are mainly due to local conditions (e.g., hydrodynamic and wind exposure) rather than customary factors such as, trophic status and depth of the euphotic zone. In this circumstance, the location and the establishment of aquatic macrophyte assemblages basically arise from the physical protection of the environment (shelter), and complementarily the availability of the light and nutrients. In this context, this study aimed at describing and comparing the incidence of aquatic macrophytes in a throughflowing, non-dendritic (i.e., with relatively low value of shoreline development) tropical reservoir.

\section{Material and Methods}

\subsection{Study area}

The Ourinhos Reservoir is located in the Middle Paranapanema basin, on the boundary of São Paulo and Paraná states (between the coordinates 4943'14", 


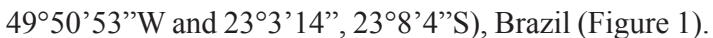
Ourinhos, Canitar, Chavantes, Ribeirão Claro and Jacarezinho are surrounding municipalities of the reservoir; in the municipality of Ourinhos, the climate is Am type (Köppen, 1931) that characterizes the tropical rainy climate with dry winter where the least rainy month has less than $60 \mathrm{~mm}$ precipitation and the coldest month has an average temperature above $18^{\circ} \mathrm{C}$ occurs (CEPAGRI, 2008; SIGRH, 2008).

The reservoir was formed in 2005 by the damming of Paranapanema River, in order to support a hydroelectric power plant (HPP Ourinhos). It is a small (area: $6.82 \mathrm{~km}^{2}$; maximum length: $17.35 \mathrm{~km}$ ), narrow (maximum width: $1.53 \mathrm{~km}$; mean width: $0.39 \mathrm{~km}$; shore line: $44.05 \mathrm{~km}$; shoreline development $\left(\mathrm{D}_{\mathrm{L}}\right)$ : 4.76), and shallow (base quota: $386 \mathrm{~m}$ a.s.1.; maximum depth: $12 \mathrm{~m}$; mean depth: $3.1 \mathrm{~m}$; relative depth: $0.41 \%$; volume development $\left.\left(D_{V}\right): 0.76\right)$. The fetch values of reservoir range from 0.7 to $3.4 \mathrm{~km}$ (mean: $2.2 \mathrm{~km}$ ). The Ourinhos Reservoir with volume of ca. $20.82 \times 10^{6} \mathrm{~m}^{3}$ (maximum operational elevation: $398 \mathrm{~m}$ a.s.1.; average flow (1937-1989): $289.2 \mathrm{~m}^{3} \mathrm{~s}^{-1}$ ) presents a low retention time (average: 0.83 days); the low retention time of this reservoir leads to ca. 438 water renewals per year. It is the fifth reservoir (in upstream-downstream) of the complex of dams that succeed in Paranapanema River. This watershed stretch $\left(16,751 \mathrm{~km}^{2}\right.$, ANA, 2006) encompasses several small cities and large rural occupations, whose predominant activity is intensive agriculture (Nogueira, 2005), pasture and reforestation.

\subsection{Limnological surveys}

From February 2006 to November 2007, eight limnological surveys were performed quarterly within the Ourinhos Reservoir and in the mouth areas of its tributaries (Santo Antônio, Colossinho and Ribeirão Claro streams; Figure 1). The positions of the sampling stations (SS) are: SS1: Santo Antônio Stream (UTM 22S, 680341, 7432.177); SS2: downstream of the Ourinhos Reservoir dam (Paranapanema River - UTM 22S, 666025, 7438040); SS3: Ribeirão Claro Stream (UTM 22S, 679315, 7434954); SS4: further upstream (Paranapanema River downstream of the Chavantes Reservoir - UTM 22S, 669077, 7438641); SS5: the Colossinho Stream (UTM 22S, 679319, 7434945); SS6: the lacustrine zone of Ourinhos Reservoir (upstream of the dam - UTM 22S, 623675, 7445036).

In each SS, the following variables were measured at each $10 \mathrm{~cm}$ (from the surface to the bottom) with a multi-parameter sonde (YSI, model 6600): electrical conductivity (EC), dissolved oxygen (DO), temperature (air: Ta; water: Tw), oxidation-reduction potential (ORP), total dissolved solids (TDS), turbidity, $\mathrm{pH}$, chlorophyll- $a$. Water samples were also collected for determination of color, alkalinity, coliforms, BOD, COD and Org-N concentrations were determined according to APHA et al. (1998). Inorganic nitrogen compounds (Inorg- $\mathrm{N}=\mathrm{NH}_{4}-\mathrm{N}$ $+\mathrm{NO}_{2}-\mathrm{N}+\mathrm{NO}_{3}-\mathrm{N}$ ) and phosphorus were determined according to colorimetric methods (Koroleff, 1976; Mackereth et al., 1978). DOC, DIC (TC = DOC + DIC) were determinate by combustion/non-dispersive infrared gas analysis method (Shimadzu analyzer, model 5000A). Maximum depth $\left(\mathrm{z}_{\max }\right)$ and Secchi disk transparency $\left(\mathrm{z}_{\mathrm{sd}}\right)$ depth were also measured. The depths of euphotic zone $\left(\mathrm{z}_{\mathrm{eu}}\right)$ were calculated from the Secchi disk disappearance depths $\left(\mathrm{z}_{\mathrm{eu}}=\mathrm{z}_{\mathrm{sd}} \times 1.88\right)$, according to French et al. (1982).

The sum of tributaries flow was calculated from the budget between the output flows of hydroelectric power plant and the affluent flows from the Paranapanema River;

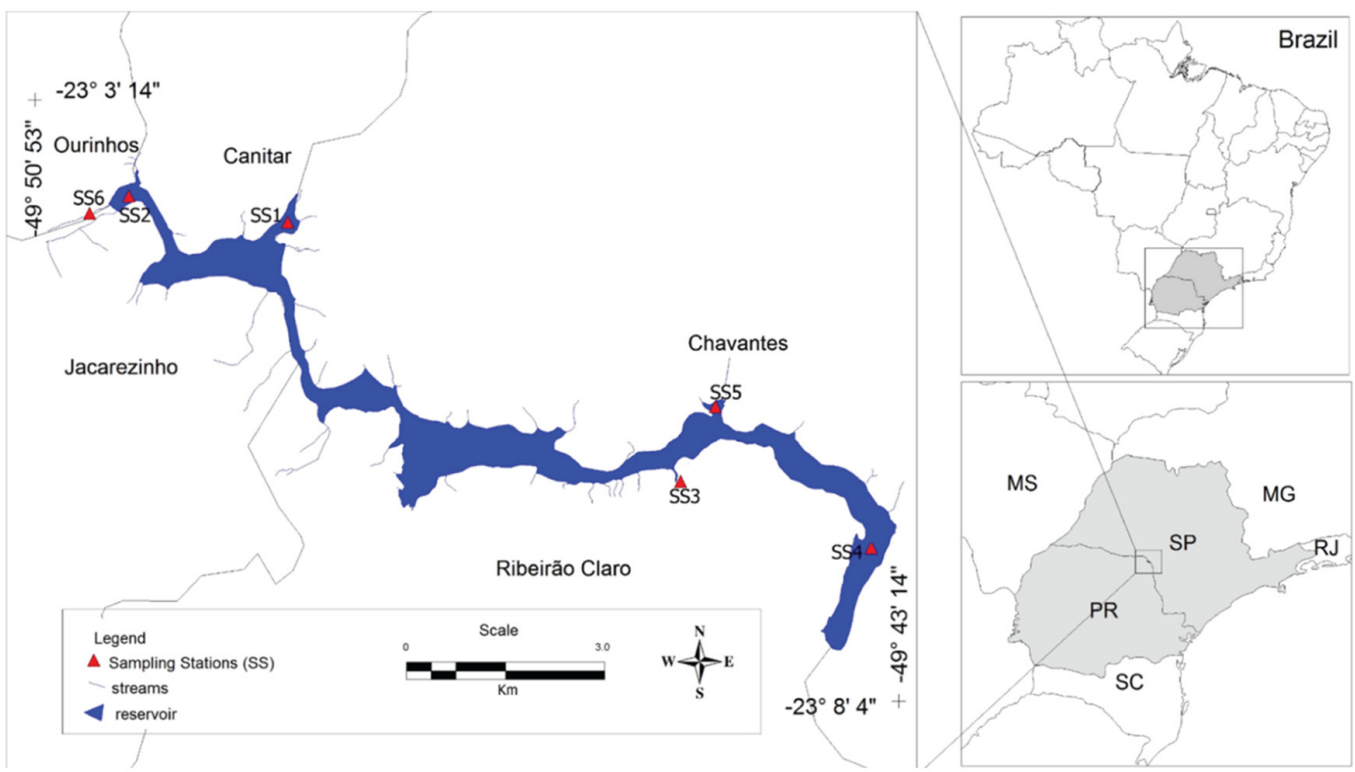

Figure 1. Reservoir and sampling stations (SS1: Santo Antonio Stream; SS2: downstream of the Ourinhos Reservoir dam; SS3: Ribeirão Claro Stream; SS4: Paranapanema River downstream of the Chavantes Reservoir; SS5: Colossinho Stream; SS6: lacustrine zone of Ourinhos Reservoir). 
the change in water level was also recorded. According to the monthly average output flows (January 2006 to December 2007) and morphometric characteristics of reservoir (volume, length and mean depth), the chronological variations in retention time (RT) and in densimetric Froude number $\left(\mathrm{F}_{\mathrm{d}}\right)$ were calculated (Orlob et al., 1969).

\subsection{Aquatic macrophytes mapping}

Mapping of plants was done throughout the reservoir quarterly, with a satellite navigation receiver (GPS Garmin, model Jeko). In each occurrence site, the plants were collected and, identified to lowest taxonomic level, according to Sculthorpe (1967), Joly (1977), Hoehne (1979), Cronquist (1981), Notare (1992), Scremin-Dias et al. (1999), Lorenzi (2000) and Pott and Pott (2000).

The mean occurrence percentages were calculated based on the presence of macrophytes in each location (the ratio between the number of sites with a given species and the total number of sites containing macrophytes), considering the eight surveys. Constancy was calculated according to the occurrence of the species (anywhere) in the eight inventories (Bodenheimer, 1938; Equation 1). The mean frequencies refer to the occurrence of the species (or family and life form) compared to the total of plants that have been identified in the each survey. Thus, occurrence refers to spatial distribution and frequency with composition of species.

$C=\frac{P \times 100}{N}$

where: $\mathrm{P}=$ number of surveys containing the species; $\mathrm{N}=$ total number of surveys.

In order to verify the differences among the SS, discriminant function analysis was employed by using chemical, physical and biological variables. After the SS differentiation by discriminant function analysis, the mean values were used for the similar SS. The macrophytes distributions were also used in discriminant function analysis to distinguish the SS (Legendre and Legendre, 1998). Stepwise multiple linear regressions were employed to attest the dependence of macrophytes and the limnological variables (confidence interval: 95\%), using XLSTAT Version 2008.3.01 software. The ANOVA F-test was also used to compare all variables among the sampling stations.

\section{Results}

During the study period, the reservoir displayed low retention times (range: 0.61 to 1.31 days; Figure 2) without a clear trend of variation during rainy period (ca. October-February) and dry season (March to September). On average, the densimetric Froude number was $22.6 \pm 5.4$ and ranged between 15.7 and 34.6 (Figure 2). The reservoir level was relatively stable at the operational level, ranging between -29 and $+32 \mathrm{~cm}$ in the region near to the dam (CBA, 2007). The budget between the output and Paranapanema River input flows (CBA, 2007) showed that, on average, the tributaries support with ca. $0.13 \pm 1.67 \%$ of water content. Thus, the Paranapanema River constitutes the main source of water of Ourinhos Reservoir.

Basing on the variables measured, the discriminant function analysis did not point out differences among the results obtained in SS along the Ourinhos Reservoir (Figure 3); therefore, the results of these locations (SS2, SS4, SS6), shown in Table 1, were pooled. High values of turbidity, color, alkalinity, DIC, TC, TDS, EC, Ta, Tw, chlorophyll-a were observed in SS1, while SS3 (high values) and SS5 (less intensity than SS3) were segregated by:
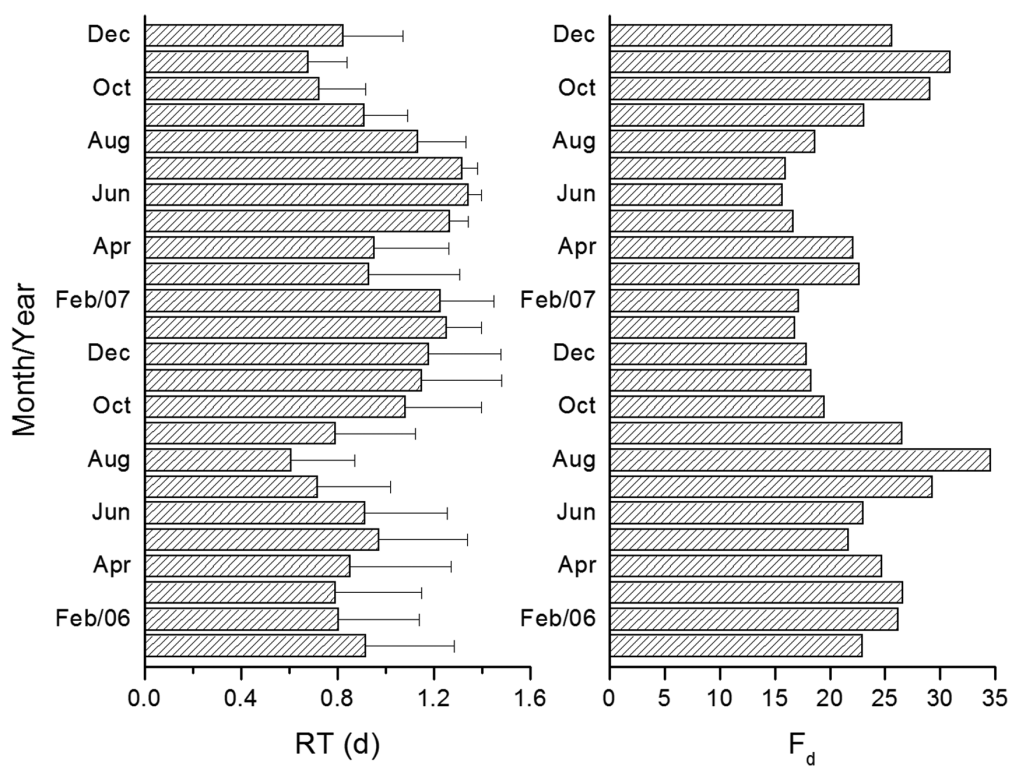

Figure 2. Temporal changes in the average of retention time (bars: standard deviation) and in the densimetric Froude number from Ourinhos Reservoir. 


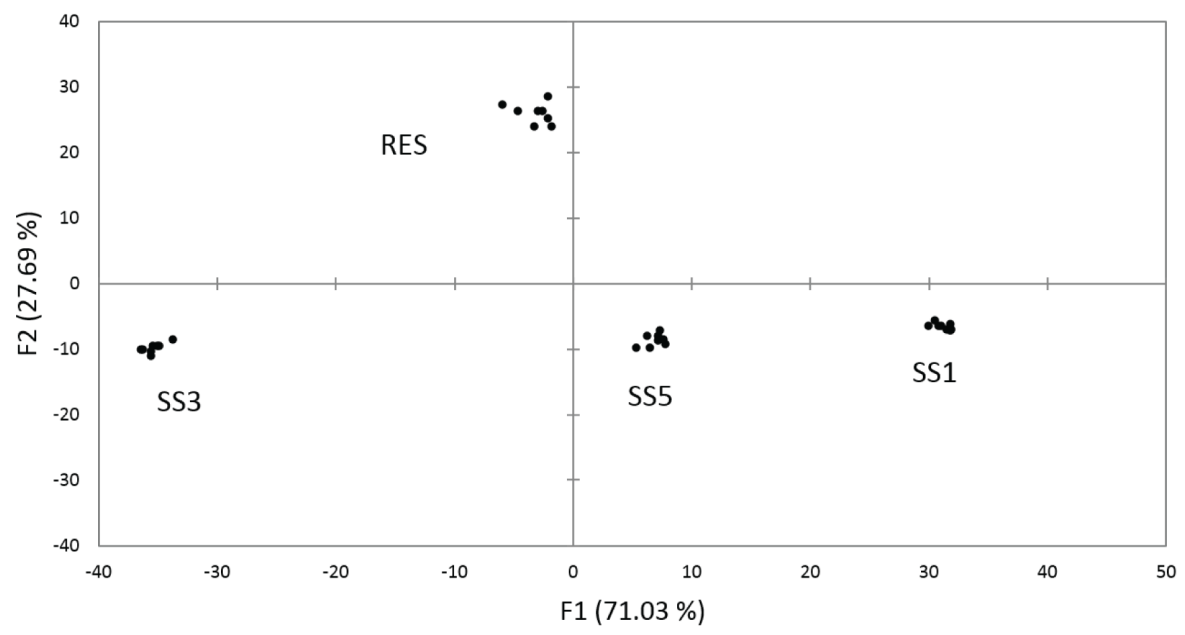

Observations (axis F1 and F2: $99.75 \%$ )

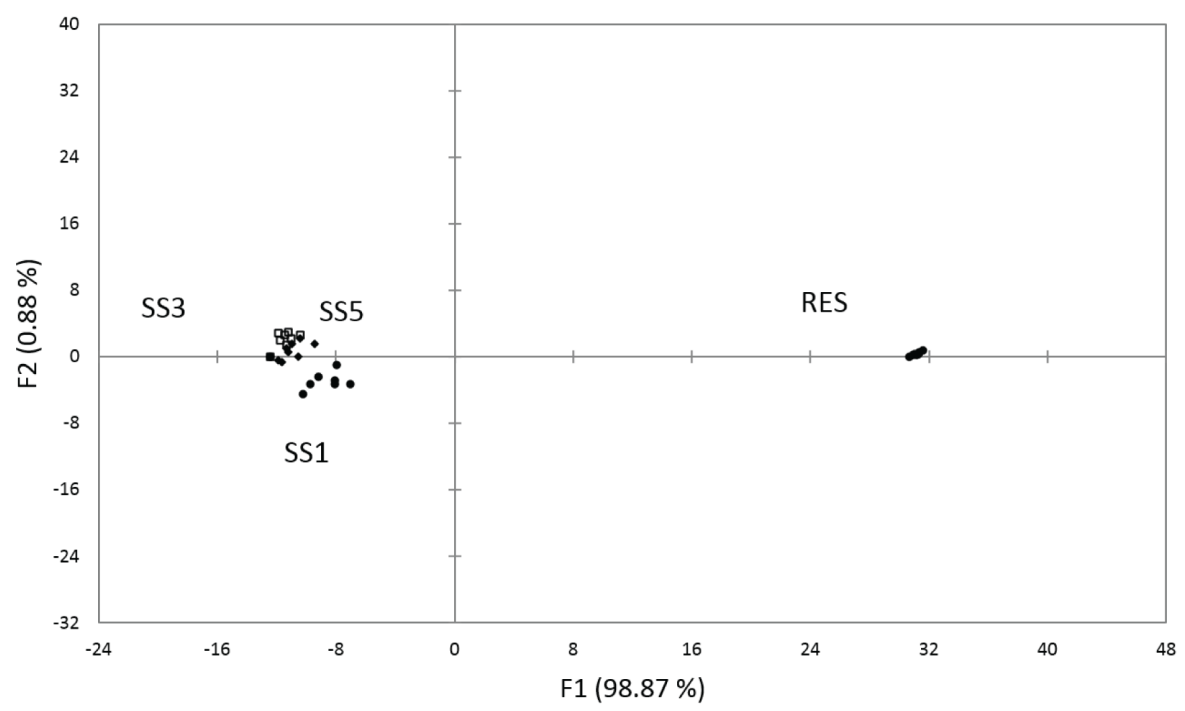

Figure 3. The sampling stations differentiation using the relative macrophytes distribution (a) and chemical, physical and biological variables (b) through discriminant function analysis.

$\mathrm{NO}_{3}-\mathrm{N}$, Inorg-N; coliforms (total and fecal), DP, TP and low N:P ratios. The SS of reservoir were discriminated by the high values of following variables: $\mathrm{z}_{\max }, \mathrm{z}_{\mathrm{eu}}, \mathrm{z}_{\mathrm{sd}}$ and $\mathrm{N}: \mathrm{P}$ ratio.

The Ourinhos Reservoir is an oligo-mesoeutrophic (sensu Vollenweider, 1968); clear water (i.e., low turbidity, low color, $\mathrm{z}_{\mathrm{eu}}$ ca. $5 \mathrm{~m}$ ) and neutral-alkaline environment (pH: 7.2-7.7; Table 1). The DO concentrations are always near to the saturation values (range: 95.2-123\%), maintaining high ORP values (range: $97-155 \mathrm{mV}$ ). The water of reservoir presents low alkalinity $\left(23.3 \pm 2.6 \mathrm{mg} \mathrm{L}^{-1}\right)$ and low concentration of nitrogen compounds (with nitrate being the predominant form of inorganic nitrogen (88.8-99.6\%) and $\mathrm{N}: \mathrm{P}$ ca. 16. The water of this reservoir also presents low concentrations of carbon (organic and inorganic), low values of the $\mathrm{EC}, \mathrm{BOD}, \mathrm{COD}$, total and fecal coliforms and chlorophyll- $a$. On the other hand, the tributaries tended to present highest values to EC, turbidity, TDS, TP, Inorg-N, Org-N, color, TC, alkalinity, coliforms (total and fecal), and lower values to DO, ORP, chlorophyll- $a$ and $z_{\text {eu }}$. The N:P rate in all tributaries were lower than that registered to reservoir. Comparing the variables of the reservoir and its tributaries, the analysis of variance (F-test) indicated significant differences (P: 0.459 to 0.001 ) among all the sites. The reservoir and its tributaries presented the same order of magnitude to BOD $\left(0.0-3.0 \mathrm{mg} \mathrm{L}^{-1}\right)$, COD (3.0-32.0 $\left.\mathrm{mg} \mathrm{L}^{-1}\right)$, and $\mathrm{pH}$ (7.0-7.9).

Among the tributaries, Ribeirão Claro Stream (SS3) presented the highest values of coliforms (total and fecal), color, DOC, COD, nitrogen (except $\mathrm{NH}_{4}-\mathrm{N}$ ) and phosphorous. Santo Antônio Stream (SS1) presented the lowest value (2.6) of N:P and the highest values of turbidity 
Table 1. Means and standard deviations (SD) of limnological variables of Ourinhos Reservoir (from February 2006 to November 2007; $\mathrm{n}=8$ ).

\begin{tabular}{|c|c|c|c|c|c|c|c|c|}
\hline & \multicolumn{2}{|c|}{ Reservoir } & \multicolumn{2}{|c|}{ SS1 } & \multicolumn{2}{|c|}{ SS3 } & \multicolumn{2}{|c|}{ SS5 } \\
\hline & Mean & SD & Mean & SD & Mean & SD & Mean & SD \\
\hline $\mathrm{EC}\left(\mu \mathrm{S} \mathrm{cm}^{-1}\right)$ & 61.8 & 4.48 & 92.8 & 17.8 & 75.8 & 8.34 & 97.5 & 20.6 \\
\hline $\mathrm{DO}\left(\mathrm{mg} \mathrm{L}^{-1}\right)$ & 9.2 & 0.98 & 6.3 & 2.4 & 9.1 & 1.32 & 9.0 & 1.12 \\
\hline $\mathrm{Ta}\left({ }^{\circ} \mathrm{C}\right)$ & 21.5 & 2.6 & 21.2 & 2.5 & 20.2 & 3.3 & 21.0 & 2.9 \\
\hline $\operatorname{Tw}\left({ }^{\circ} \mathrm{C}\right)$ & 23.5 & 2.86 & 21.7 & 3.07 & 21.5 & 3.3 & 22.3 & 2.68 \\
\hline ORP (mV) & 126.0 & 16.9 & 98.7 & 59.4 & 121.4 & 24.1 & 131.9 & 15.2 \\
\hline $\operatorname{TDS}\left(\mu \mathrm{g} \mathrm{L}^{-1}\right)$ & 40.1 & 3.0 & 60.4 & 11.6 & 49.3 & 5.3 & 63.4 & 13.4 \\
\hline Turbidity (NTU) & 2.9 & 1.35 & 16.8 & 18.5 & 13.4 & 12.5 & 10.3 & 4.59 \\
\hline $\mathrm{pH}$ & 7.5 & 0.2 & 7.2 & 0.14 & 7.6 & 0.2 & 7.4 & 0.19 \\
\hline Chlorophyll- $a\left(\mu \mathrm{g} \mathrm{L}^{-1}\right)$ & 0.9 & 0.54 & 0.7 & 0.32 & 0.7 & 0.32 & 1.0 & 0.86 \\
\hline $\mathrm{TP}\left(\mu \mathrm{g} \mathrm{L}^{-1}\right)$ & 9.8 & 3.72 & 31.2 & 18.7 & 50.7 & 12.9 & 20.2 & 12.8 \\
\hline $\mathrm{DP}\left(\mu \mathrm{g} \mathrm{L}^{-1}\right)$ & 5.5 & 4.44 & 19.3 & 16 & 37.8 & 14.8 & 11.5 & 9.0 \\
\hline $\mathrm{PP}\left(\mu \mathrm{g} \mathrm{L}^{-1}\right)$ & 4.3 & 1.72 & 11.9 & 7.94 & 12.9 & 6.89 & 8.7 & 7.37 \\
\hline $\mathrm{NH}_{4}-\mathrm{N}\left(\mu \mathrm{g} \mathrm{L}^{-1}\right)$ & 4.8 & 5.03 & 10.7 & 11.2 & 31.8 & 20.1 & 51.8 & 73 \\
\hline $\mathrm{NO}_{2}-\mathrm{N}\left(\mu \mathrm{g} \mathrm{L}^{-1}\right)$ & 1.5 & 1.23 & 3.2 & 3.56 & 23.2 & 28.8 & 12.5 & 26.5 \\
\hline $\mathrm{NO}_{3}-\mathrm{N}\left(\mu \mathrm{g} \mathrm{L}^{-1}\right)$ & 135.9 & 39.1 & 35.5 & 26 & 447.2 & 253 & 122.4 & 50.3 \\
\hline Inorganic-N ( $\left.\mu \mathrm{g} \mathrm{L}^{-1}\right)$ & 142.1 & 39 & 49.4 & 28 & 502.1 & 270 & 186.7 & 57.1 \\
\hline Organic-N ( $\left.\mu \mathrm{g} \mathrm{L}^{-1}\right)$ & 536.9 & 131 & 587.2 & 256 & 787.0 & 252 & 598.2 & 273 \\
\hline $\mathrm{N}: \mathrm{P}$ & 16.3 & 7.33 & 2.6 & 2.28 & 9.8 & 3.92 & 12.2 & 6.64 \\
\hline Color (mg Pt L $\left.{ }^{-1}\right)$ & 20.3 & 9.92 & 143.3 & 128 & 82.5 & 40.4 & 26.5 & 13.7 \\
\hline $\mathrm{BOD}\left(\mathrm{mg} \mathrm{L}^{-1}\right)$ & 1.5 & 0.61 & 1.0 & 0.74 & 1.6 & 0.49 & 1.2 & 0.75 \\
\hline $\operatorname{COD}\left(\mathrm{mg} \mathrm{L}^{-1}\right)$ & 7.6 & 2.4 & 12.8 & 9.85 & 13.0 & 5.66 & 7.1 & 3.91 \\
\hline $\mathrm{TC}\left(\mathrm{mg} \mathrm{L}^{-1}\right)$ & 7.5 & 1.66 & 13.0 & 5.4 & 9.0 & 2.24 & 8.6 & 2.4 \\
\hline $\mathrm{DOC}\left(\mathrm{mg} \mathrm{L}^{-1}\right)$ & 2.1 & 0.75 & 2.2 & 1.23 & 3.1 & 1.3 & 1.8 & 1.16 \\
\hline $\mathrm{DIC}\left(\mathrm{mg} \mathrm{L}^{-1}\right)$ & 5.4 & 1.07 & 10.7 & 4.4 & 5.9 & 1.45 & 6.8 & 2.31 \\
\hline Alkalinity $\left(\mathrm{mg} \mathrm{L}^{-1}\right)$ & 23.3 & 2.6 & 39.9 & 7.08 & 25.0 & 2.51 & 23.9 & 2.75 \\
\hline Total coliform (MPN) & 5,343 & 6,380 & 7,650 & 6,184 & 60,375 & 41,442 & 11,587 & 5,370 \\
\hline Fecal coliform (MPN) & 192 & 160 & 672 & 472 & 5,200 & 2,704 & 1,886 & 1,624 \\
\hline $\mathrm{z}_{\mathrm{eu}}(\mathrm{m})$ & 5.5 & 1.39 & 1.2 & 0.34 & 2.6 & 0.83 & 2.3 & 1.16 \\
\hline $\mathrm{z}_{\max }(\mathrm{m})$ & 6.9 & 4.3 & 0.7 & 0.1 & 2.6 & 0.9 & 1.3 & 0.7 \\
\hline $\mathrm{z}_{\mathrm{sd}}(\mathrm{m})$ & 2.9 & 1.6 & 0.7 & 0.2 & 1.4 & 0.4 & 1.2 & 0.6 \\
\hline
\end{tabular}

SS1 = Santo Antônio Stream; SS3: Ribeirão Claro Stream; SS5: Colossinho Stream; Reservoir: average data from SS2, SS4 and SS6.

$(16.8 \pm 18.5 \mathrm{NTU})$, alkalinity $\left(39.9 \pm 7.1 \mathrm{mg} \mathrm{L}^{-1}\right)$ and of DIC $\left(10.7 \pm 4.4 \mathrm{mg} \mathrm{L}^{-1}\right)$ concentrations. The Colossinho Stream (SS5) presented the highest concentrations for chlorophyll- $a$, TDS and $\mathrm{NH}_{4}-\mathrm{N}$ and for, electrical conductivity and ORP (Table 1).

The number of sites with macrophytes ranged from 21 to 38, and of the species between 10 and 15 (Figure 4). Eighteen species of aquatic macrophytes were identified comprising 12 families (Table 2), and in the final of $1 \mathrm{st}$ year the total number of species was found (Figure 4). Cyperaceae, Pontederiaceae and Onarograceae were the families with highest number of species. The number of sites registered with the plants varied between 21 (May 2006) and 38 (May 2007); average $=28.3 \pm 5$. Seven species were always present (E. azurea, E. crassipes, Eleocharis sp1, M. aquaticum, O. cubense, S. auriculata, T. domingensis), and were more frequent in the sites ( $T$. domingensis:
51.9\%; M. aquaticum: $35.1 \%$; S. auriculata: $17.3 \%$; E. azurea: 17.0\%; Eleocharis sp1: 16.9\%; E. crassipes: $14.4 \%$; O. cubense: $10.9 \%$ ); Figure 5. Considering the life form (Figure 5), the occurrence of emergent species predominated in Ourinhos Reservoir (45.9\%), followed by submersed rooted $(24.5 \%)$, free floating (19.5\%), floating rooted $(9.7 \%)$ and free submersed $(0.3 \%)$.

Basing on macrophytes, the discriminant function analysis pointed out differences among the SS located in the tributaries and along the Ourinhos Reservoir (Figure 3). The species richness was higher in reservoir (18 species) than in tributaries (SS1: 7 species; SS3: 8 species; SS5: 5 species). The family Thyphaceae (represented by T. domingensis) was predominant considering constancy and incidence in sites. T. domingensis and M. aquaticum were considered common $(10 \%<$ frequency $(\mathrm{F}) \leq 50 \%$; sensu Lobo and Leighton, 1986), the remaining taxa 

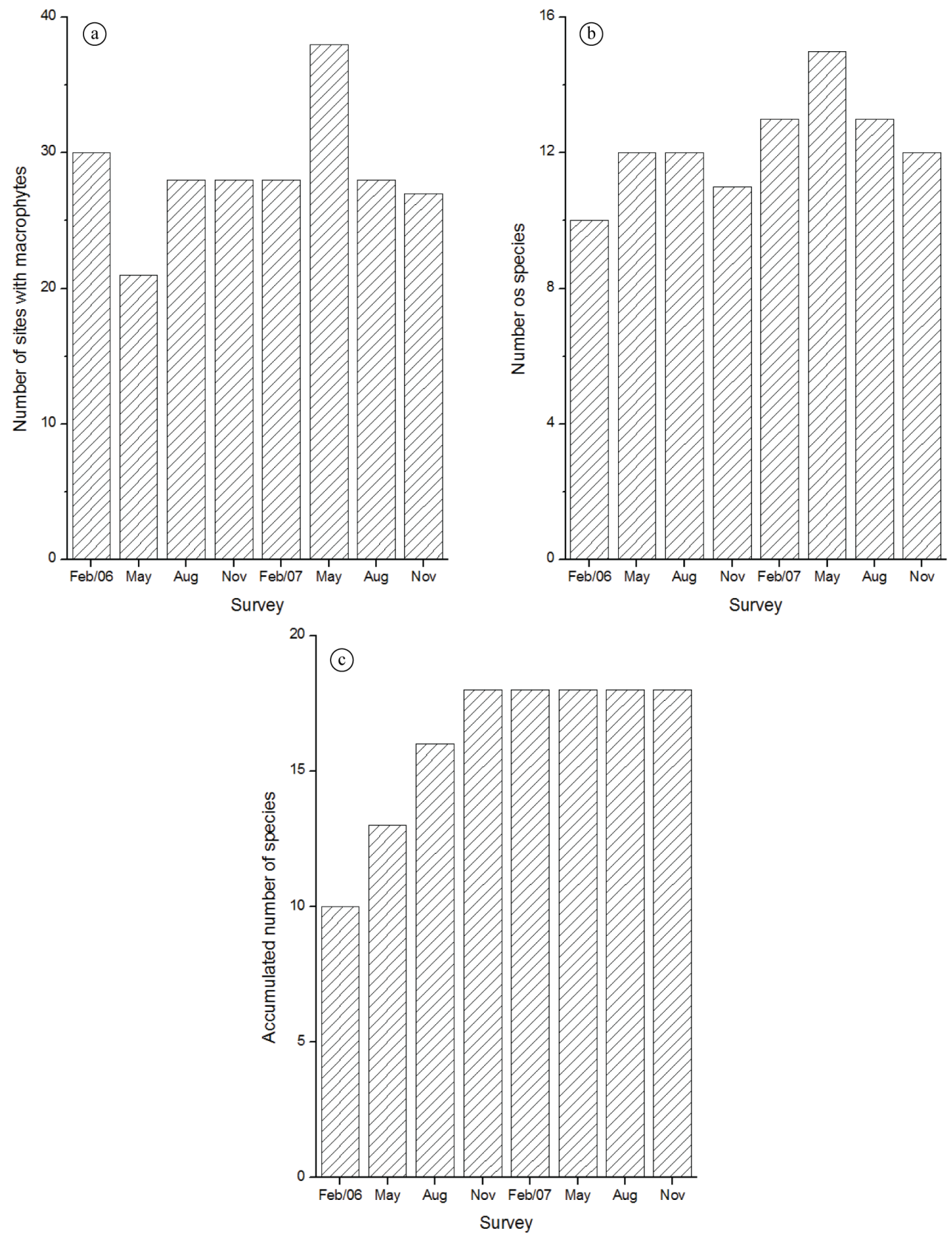

Figure 4. Change in the number of sites with macrophytes in the Ourinhos Reservoir (a), number of the species registered per survey (b), and accumulate number of species (c).

were considered rare $(\mathrm{F} \leq 10 \%)$. None macrophyte was classified as constant (i.e., F> 50\%) in the Ourinhos Reservoir. The frequencies of the two common species (T. domingensis and M. aquaticum) were $26.4 \pm 5.9 \%$ and $17.4 \pm 3.1 \%$, respectively (Figure 6).
Regardless the set of variables used (i.e., limnological variables or macrophytes), the discriminant function analysis did not indicate differences among the SS along the Ourinhos Reservoir (Figure 3). Taking into account the macrophytes distribution, the discriminant function analysis 
Table 2. Taxa registered during the surveys $(n=8)$ on the Ourinhos Reservoir and tributaries (February/06 - November/07).

\begin{tabular}{|c|c|c|}
\hline Family & Taxa & Life form \\
\hline Alismataceae & Echinodorus macrophyllus (Kunth) Micheli & Emergent \\
\hline Apiaceae & Hydrocotyle ranunculoides L. f. & Free floating \\
\hline Araceae & Pistia stratiotes L. & Free floating \\
\hline Azollaceae & Azolla caroliniana Willd. & Free floating \\
\hline \multirow[t]{3}{*}{ Cyperaceae } & Eleocharis sp1 & Emergent \\
\hline & Eleocharis sp2 & Emergent \\
\hline & Oxycaryum cubense (Poepp. \& Kunth) Lye & Emergent \\
\hline Haloragaceae & Myriophyllum aquaticum (Vell.) Verdec & Submersed rooted \\
\hline Lentibulariaceae & Utricularia $\mathrm{sp}$ & Free submersed \\
\hline Nymphaeaceae & Nymphaea elegans Hook. & Floating rooted \\
\hline \multirow[t]{3}{*}{ Onagraceae } & Ludwigia sp1 & Submersed rooted \\
\hline & Ludwigia sp2 & Submersed rooted \\
\hline & Ludwigia sp3 & Submersed rooted \\
\hline \multirow[t]{3}{*}{ Pontederiaceae } & Eichhornia azurea (Sw.) Kunth & Floating rooted \\
\hline & Eichhornia crassipes (Mart.) Solms & Free floating \\
\hline & Heteranthera multiflora (Griseb.) Horn & Free floating \\
\hline Salviniaceae & Salvinia auriculata Aubl. & Free floating \\
\hline Typhaceae & Typha domingensis Pers. & Emergent \\
\hline
\end{tabular}
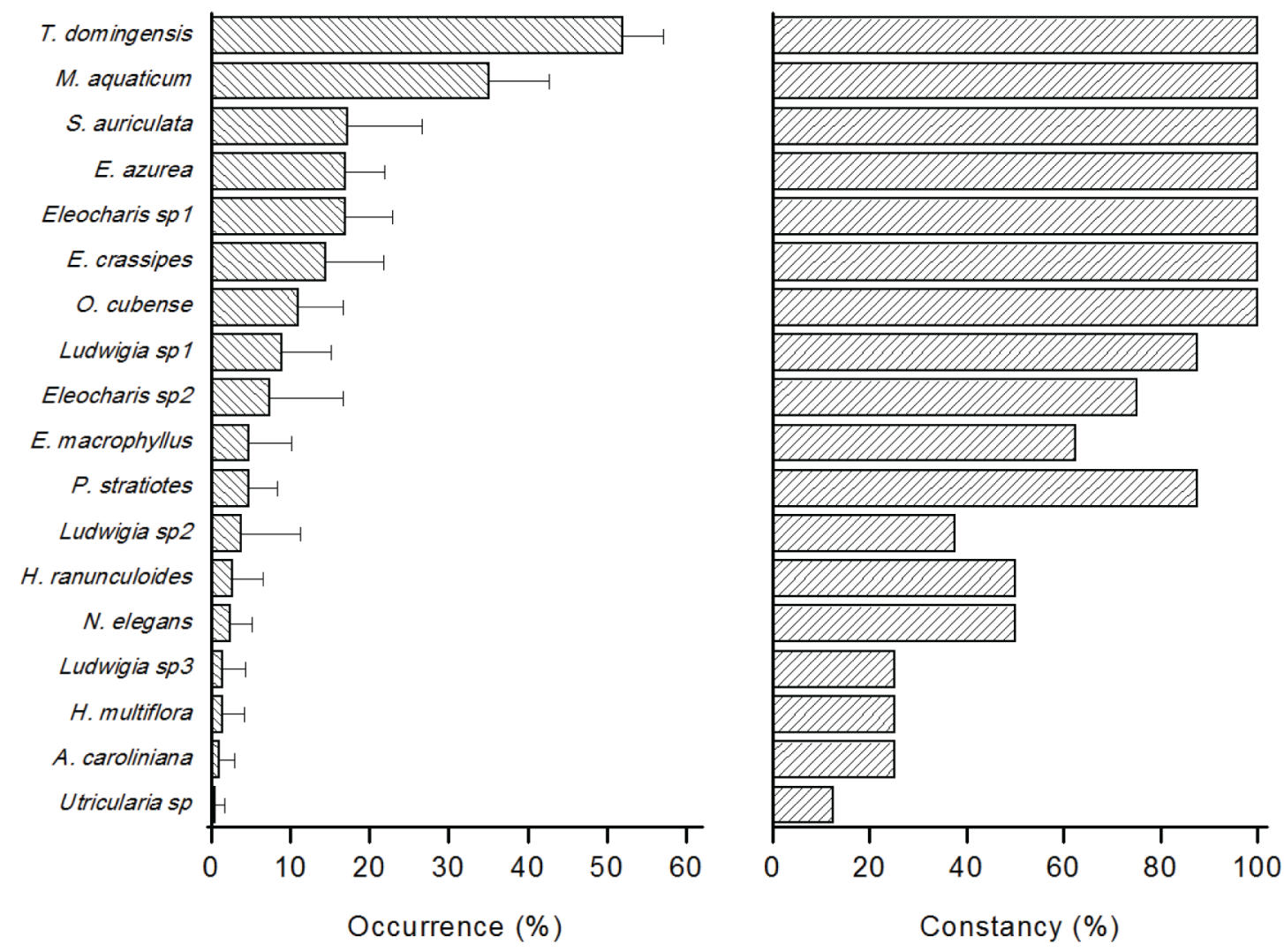

Figure 5. Average of occurrence (bars: standard deviation) and constancy of aquatic macrophytes in the Ourinhos Reservoir from February 2006 to November 2007. 
(a)
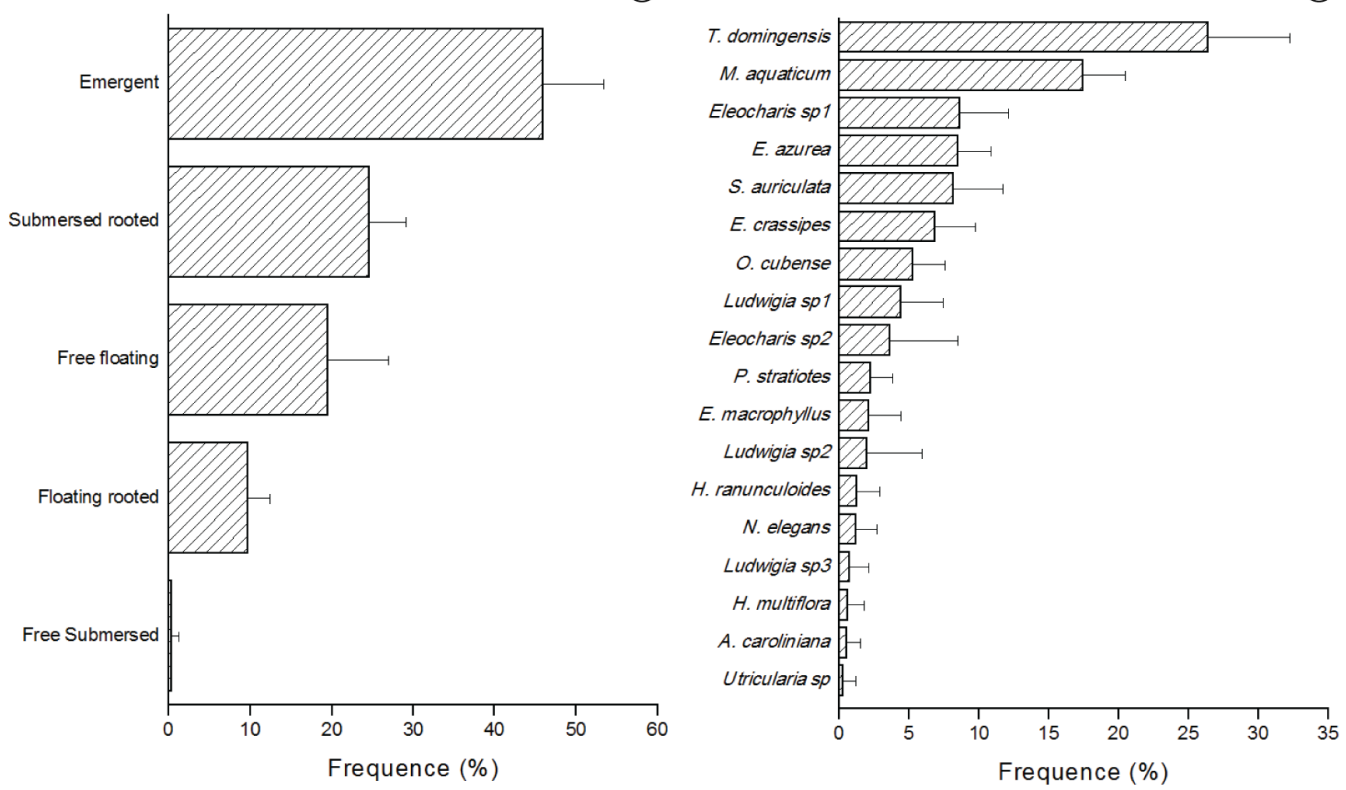

(c)

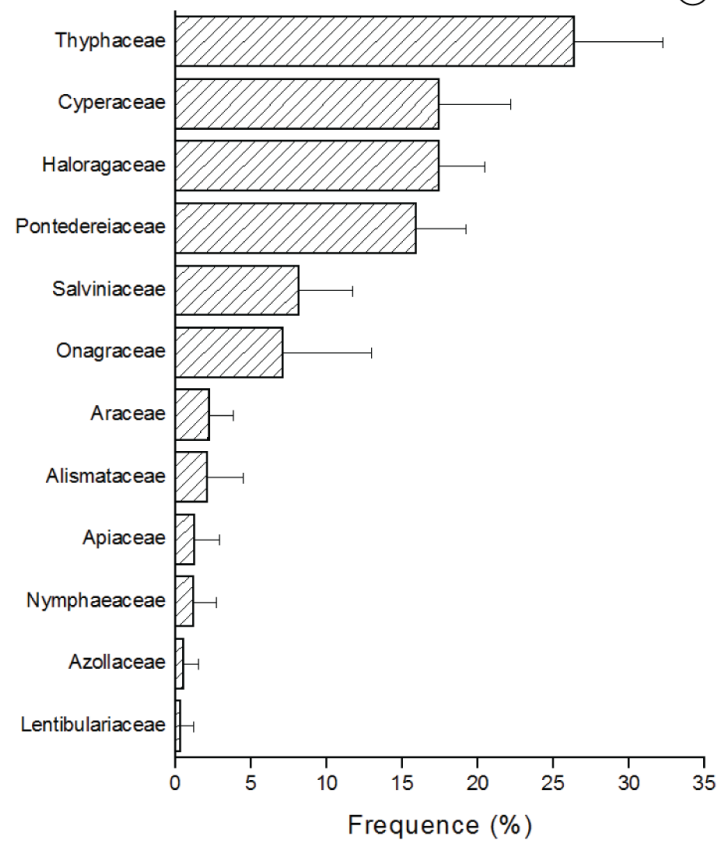

Figure 6. Average of frequencies (bars: standard deviation) of aquatic macrophytes according their life forms (a), species (b) and families (c in Ourinhos Reservoir.

indicated that the SS1 was characterized by the incidence of $N$. elegans, in spite of low frequency; $H$. ranunculoides, H. multiflora, Ludwigia sp3, E. macrophyllus discriminated SS3 and SS5, with higher incidences in SS3 than SS5. Higher incidence of macrophytes species discriminated the reservoir sites. Overall, the differences were basically found among the tributaries SS1, SS3 and SS5 and the reservoir sites (SS2; SS4 and SS6).
The stepwise multiple linear regressions attest the following correspondences for the most constant (87.5 to $100 \%)$ and distributed macrophytes and the limnological variables: T. domingensis: DOC; M. aquaticum: BOD; S. auriculata: alkalinity; E. azurea: Org-N; Eleocharis $\mathrm{sp} 1$ : color and DO; E. crassipes: $\mathrm{z}_{\max }$; O. cubense: ORP and BOD; P. stratiotes: $\mathrm{z}_{\mathrm{eu}}$; Ludwigia sp 1: $\mathrm{z}_{\max }$ and fecal coliforms. 


\section{Discussion}

All aquatic macrophytes recorded in Ourinhos Reservoir are common in Neotropical reservoirs and lakes (Vilarrubia and Cova, 1993; Bini et al., 1999, 2005; Neiff, 2001; Nahlik and Mitsch, 2006; Neiff et al., 2008; Martins et al., 2008; Bianchini Junior et al., 2010; Henry-Silva et al., 2010; Piedade et al., 2010; Rolon et al., 2010; Alves Ferreira et al., 2011). In the Paranapanema watershed, these species were also usually recorded in the following reservoirs: Rosana, Salto Grande, Chavantes, Piraju and Jurumirim (Henry and Nogueira, 1999; Casatti et al., 2003; Martins et al., 2008; Neves, 2008; Bianchini Junior and Cunha-Santino, 2014). In particular, in Ourinhos Reservoir, the seven species with highest occurrence (i.e., 100\%: T. domingensis; M. aquaticum; S. auriculata; E. azurea; Eleocharis sp1; E. crassipes; O. cubense) showed the highest distribution and highest frequency. The remaining 11 taxa tended to present sporadic occurrence with low distribution and could be categorized as rare.

The morphometric (shallow, narrow, wind-swept, not dendritic) and hydraulic features (low RT and high $\mathrm{F}_{\mathrm{d}}$ values), and the type of HPP operation (that encompass low variation in water level) categorized this aquatic system as run-of-the-river (Arcifa and Esguícero, 2012) and rapidly throughflowing reservoir (Straškraba, 1999), in which the vertical circulation of water is continually favored; thus, thermal stratification is not expected (i.e., $F_{d}>1 / \pi$ ). Due to the morphometric features (length and mean depth) of Ourinhos Reservoir, the thermal stratification can only occur when its RT would be higher than 66 days. The contribution of tributaries do not exerts influence on chemical and physical characteristics of reservoir water, once its flows are very low (less than 1\%) compared with from the Paranapanema River. In addition, the low residence times did not allow the occurrence of a well-marked longitudinal gradient of limnological variables, as expected to artificial reservoirs (Kimmel et al., 1990). Thus, the chemical and physical constraints imposed by Ourinhos Reservoir waters to aquatic macrophytes community generate a predominance of emergent species, from Typhaceae, Cyperaceae and Alismataceae families. The species related with these families are predominantly located in the littoral region of the reservoir.

Although limnological variables and the distribution of macrophytes have discriminated similarly the sampling points, the stepwise multiple linear regressions did not pointed out strong correspondences (or coherence) among the most constant and distributed macrophyte species and the selected limnological variables, as well the trophic status (Table 3). The incidence degree of submersed species owed the constancy and distribution of $M$. aquaticum. Because it is rooted, this species may not be directly dependent on the chemical characteristics of the water (i.e., nutrient availability), but may be affected by the availability of light (Hussner et al., 2009; Wersal and Madsen, 2011). On the other hand, the free submersed species (Utricularia sp), that depends on a more sheltered place and dissolved nutrients availability, did not present a good settlement performance (Lacoul and Freedman, 2006). Low constancy and incidence of Utricularia sp are linked with the low DIC and alkalinity concentrations (Carr et al., 1997; Vestergaard and Sand-Jensen, 2000). With regard the distribution and frequency, floating species (rooted or free) are of secondary status in this reservoir. As verified to almost emergent species, the main floating species (E. azurea) also has linked with palustrine area, which can present local characteristics, not necessarily close to that prevail in water (Hudon et al., 2000; Santamaria, 2002; Hawes et al., 2003). Of the free-floating species, two showed high constancy (S. auriculata and E. azurea) but its incidences did not were reported to any selected variable, as well verified to $P$. stratiotes and Ludwigia sp1 that showed lower constancy $(87 \%)$.

In conclusion, in the shallow reservoir with low retention time and low DL, the hydrodynamic regime (i.e., turbulent environment) tend to prevail in order to determine the sites morphometry and, consequently, the predominant species and their distribution. In addition, the wind exposure (i.e., fetch length) determines the type of thermal circulation, as well, the favorable sites for the

Table 3. t-Student and determination coefficient $\left(\mathrm{r}^{2}\right)$ from the stepwise multiple linear regressions for most frequent and constant macrophytes species and limnological variables selected by this analysis.

\begin{tabular}{lccc}
\hline \multicolumn{1}{c}{ Macrophyte species } & Variables & t-Student & $\mathbf{r}^{\mathbf{2}}$ \\
\hline Typha domingensis & DOC & 1,631 & 0.307 \\
Myriophyllum aquaticum & BOD & 3,774 & 0.704 \\
Salvinia auriculata & Alkalinity & 2,636 & 0.537 \\
Eichhornia azurea & Org-N & 2,104 & 0.425 \\
Eleocharis sp1 & DO & $-5,170$ & 0.460 \\
& Color & $-3,809$ & 0.862 \\
Oxycaryum cubense & ORP & $-4,735$ & 0.524 \\
Eichhornia crassipes & $\mathrm{z}_{\max }$ & $-1,464$ & 0.460 \\
& BOD & 3,414 & 0.857 \\
Pistia stratiotes & $\mathrm{z}_{\text {eu }}$ & 5,795 & 0.528 \\
Ludwigia sp1 & $\mathrm{z}_{\max }$ & 4,997 & 0.467 \\
\end{tabular}


growth of plants. Considering the weak relationship among chemical and physical variables of water and macrophytes distribution, in the case of Ourinhos Reservoir the results pointed out that the water turbulence, low DL and wind exposure are main drive forces that determine its aquatic plant distribution, life forms and species composition. In this context, four species among the most frequent and constant (T. domingensis, M. aquaticum, E. azurea, Eleocharis sp1) did not depends directly of characteristics of reservoir water. Among $S$. auriculata, E. crassipes, and $O$. cubense, just $S$. auriculata presented correlation with a variable directly linked with its physiology and water characteristics (i.e., alkalinity).

\section{Acknowledgements}

The authors are grateful to Companhia Brasileira de Alumínio (CBA/Votorantim) for subsided the field sampling and for the concession of limnological data from Ourinhos Reservoir. We thank CNPq (process no $301765 / 2010-3$ ) for scholarships.

\section{References}

AGÊNCIA NACIONAL DAS ÁGUAS - ANA, 2006 [viewed 25 October 2014]. Bacia do rio Paranapanema. SGI: Superintendência de Gestão da Informação. Brasília: ANA. Available from: http:// vampira.ourinhos.unesp.br:8080/cediap/material/bacias_bacia rio_paranapanema_-_ana.pdf

AGOSTINHO, A.A., MIRANDA, L.E., BINI, L.M., GOMES, L.C., THOMAZ, S.M. and SUZUKI, H.I., 1999. Patterns of colonization in Neotropical reservoirs, and prognoses on aging. In: J.G. TUNDISI and M. STRAŠKRABA, eds. Theoretical reservoir ecology and its applications. Leiden: Brazilian Academy of Science, pp. 227-265.

AMERICAN PUBLIC HEALTH ASSOCIATION - APHA, AMERICAN WATER WORKS ASSOCIATION - AWWA, WATER ENVIRONMENT FEDERATION - WEF, 1998. Standard methods for the examination of water and wastewater. Washington, D.C.: APHA. 1193 p.

ARCIFA, M.S. and ESGUÍCERO, A.L.H., 2012. The fish fauna in the fish passage at the Ourinhos Dam, Paranapanema River. Neotropical Ichthyology, vol. 10, no. 4, pp. 715-722. http://dx.doi. org/10.1590/S1679-62252012000400004.

BIANCHINI JUNIOR, I. and CUNHA-SANTINO, M.B., 2014. Dynamics of colonization and collapse of macrophyte community during the formation of a tropical reservoir. Fundamental and Applied Limnology, vol. 184, no. 2, pp. 141-150. http://dx.doi. org/10.1127/1863-9135/2014/0491.

BIANCHINI JUNIOR, I., CUNHA-SANTINO, M.B., FUSHITA, A.T., ALMEIDA, D.A. and MAIA, A.T., 2010. Monitoramento das macrófitas aquáticas do reservatório da Usina Hidrelétrica Luís Eduardo Magalhães (Estado de Tocantins, Brasil). AUGMDOMUS, vol. 2, pp. 38-48.

BINI, L.M., OLIVEIRA, L.G., SOUZA, D.C., CARVALHO, P. and PINTO, M.P., 2005. Patterns of the aquatic macrophyte cover in Cachoeira Dourada Reservoir (GO-MG). Brazilian Journal of Biology = Revista Brasileira de Biologia, vol. 64, no. 4, pp. 767-770. PMid:16025899.
BINI, L.M., THOMAZ, S.M., MURPHY, K.J. and CAMARGO, A.F.M., 1999. Aquatic macrophyte distribution in relation to water and sediment conditions in the Itaipu Reservoir Brazil. Hydrobiologia, vol. 415, no. 0, pp. 147-154. http://dx.doi. org/10.1023/A:1003856629837.

BODENHEIMER, F.S., 1938. Problems of animal ecology. Oxford: Oxford University Press. 179 p.

BORNETTE, G. and PUIJALON, S., 2009. Macrophytes: Ecology of aquatic plants. Encyclopedia of Life Sciences. Chichester: John Wiley \& Sons Ltd.

CARR, G.M., DUTHIE, H.C. and TAYLOR, W.D., 1997. Models of aquatic plant productivity: a review of the factors that influence growth. Aquatic Botany, vol. 59, no. 3-4, pp. 195-215. http:// dx.doi.org/10.1016/S0304-3770(97)00071-5.

CASATTI, L., MENDES, H.F. and FERREIRA, K.M., 2003. Aquatic macrophytes as feeding site for small fishes in the Rosana Reservoir, Paranapanema River, Southeastern Brazil. Brazilian Journal of Biology = Revista Brasileira de Biologia, vol. 63, no. 2, pp. 213-222. http://dx.doi.org/10.1590/S151969842003000200006. PMid:14509843.

CENTRO DE PESQUISAS METEOROLÓGICAS E CLIMÁTICAS APLICADAS À AGRICULTURA - CEPAGRI, 2008 [viewed 17 October 2014]. Clima dos Municipios Paulistas [online]. Campinas: CEPAGRI. Available from: http://www.cpa.unicamp. br/outras-informacoes/clima-dos-municipios-paulistas.html

CHAMBERS, P.A., LACOUL, P., MURPHY, K.J. and THOMAZ, S.M., 2008. Global diversity of aquatic macrophytes in freshwater. Hydrobiologia, vol. 595, no. 1, pp. 9-26. http://dx.doi.org/10.1007/ s10750-007-9154-6.

COMPANHIA BRASILEIRA DE ALUMÍNIO - CBA, 2007. Dados UFSCar Ourinhos. Ourinhos: Ourinhos HPP operator. $1 \mathrm{CD}-\mathrm{ROM}$.

CRONQUIST, A., 1981. An integrated system of classification of flowering plants. New York: Columbia University Press. 1262 p.

FERREIRA, F.A., MORMUL, R.P., CATIAN, G., POTT, A. and PEDRALLI, G., 2015. Distribution pattern of neotropical aquatic macrophytes in permanent lakes at a Ramsar site. Brazilian Journal of Botany, vol. 38, no. 1, pp. 131-139. http://dx.doi.org/10.1007/ s40415-014-0105-y.

FERREIRA, F.A., MORMUL, R.P., THOMAZ, S.M., POTT, A. and POTT, V.J., 2011. Macrophytes in the upper Paraná river floodplain: checklist and comparison with other large South American wetlands. Revista de Biologia Tropical, vol. 59, no. 2, pp. 541-556. PMid:21717850.

FIGUEIREDO, D.M. and BIANCHINI JUNIOR I., 2008. Limnological patterns of the filling and stabilization phases in the Manso multiple-use Reservoir (MT). Acta Limnologica Brasiliensia, vol. 20, no. 4, pp. 277-290.

FRENCH, R.H., COOPER, J.J. and VIGG, S., 1982. Secchi disk relationships. Water Resources Bulletin, vol. 18, no. 1, pp. 121-123. http://dx.doi.org/10.1111/j.1752-1688.1982.tb04538.x.

GLIBERT, P.M., 1998. Interactions of top-down and bottom-up control in planktonic nitrogen cycling. Hydrobiologia, vol. 363, no. 1-3, pp. 1-12.

HAVEL, J.E., LEE, C.E. and ZANDEN, M.J.V., 2005. Do reservoirs facilitate invasions into landscapes? Bioscience, vol. 55, no. 6, pp. 518-525. http://dx.doi.org/10.1641/0006-3568(2005)055[0518:DR FIIL]2.0.CO;2. 
HAWES, I., RIIS, T., SUTHERLAND, D. and FLANAGAN, M., 2003. Physical constraints to aquatic plant growth in New Zealand lakes. Journal of Aquatic Plant Management, vol. 41, no. January, pp. 44-52.

HENRY, R. and NOGUEIRA, M.G., 1999. Represa de Jurumirim (São Paulo): primeira síntese sobre o conhecimento limnológico e uma proposta preliminar de manejo ambiental. In: R. HENRY, ed. Ecologia de reservatórios: estrutura, função e aspectos sociais. Botucatu: FUNDIBIO/FAPESP, pp. 653-685.

HENRY-SILVA, G.G., MOURA, R.S.T. and DANTAS, L.L.O., 2010. Richness and distribution of aquatic macrophytes in Brazilian semi-arid aquatic ecosystems. Acta Limnologica Brasiliensia, vol. 22, no. 2, pp. 147-156. http://dx.doi.org/10.1590/S2179975X2010000200004.

HOEHNE, F.C., 1979. Plantas aquáticas. São Paulo: Secretaria da Agricultura do Estado de São Paulo/Instituto de Botânica. 168 p. Série "D".

HUDON, C., LALONDE, S. and GAGNON, P., 2000. Ranking the effects of site exposure, plant growth form, water depth, and transparency on aquatic plant biomass. Canadian Journal of Fisheries and Aquatic Sciences, vol. 57, Suppl. 1, pp. 31-42.

HUSSNER, A., MEYER, C. and BUSCH, J., 2009. The influence of water level and nutrient availability on growth and root system development of Myriophyllum aquaticum. Weed Research, vol. 49, no. 1, pp. 73-80. http://dx.doi.org/10.1111/j.1365-3180.2008.00667.x.

JOLY, A.B., 1977. Botânica: introdução à taxonomia vegetal. São Paulo: Companhia Editora Nacional. 775 p.

KIMMEL, B.L., LIND, O.T. and PAULSON, L.J., 1990. Reservoir primary production. In: K.W. THORTON, B.L. KIMMEL and F.E. PAYNE, eds. Reservoir Limnology: ecological perspectives. New York: Wiley-Interscience Publication, pp. 133-193.

KÖPPEN, W., 1931. Grundriss der klimakunde. Berlin: De Gruyter. 388 p.

KOROLEFF, F., 1976. Determination of nutrients. In: K. GRASSHOFF, ed. Methods of seawater analysis. New York: Verlag Chemie Weinheim, pp. 125-131.

LACOUL, P. and FREEDMAN, B., 2006. Environmental influences on aquatic plants in freshwater ecosystems. Environmental Reviews, vol. 14, no. 2, pp. 89-136. http://dx.doi.org/10.1139/a06-001

LEGENDRE, P. and LEGENDRE, L., 1998. Numerical ecology. 2nd ed. Amsterdam: Elsevier. 853 p. Developments in Environmental Modelling, 20

LOBO, E. and LEIGHTON, G., 1986. Estruturas de las fitocenosis planctônicas de los sistemas de desembocaduras de rios y esteros de la zona central de Chile. Revista de Biologia Marina, vol. 22, no. 1, pp. 143-170.

LOPES, P.M., BINI, L.G., DECLERCK, S.A.J., FARJALLA, V.F., VIEIRA, L.C.G., BONECKER, C.C., LANSAC-TOHA, F.A., ESTEVES, F.A. and BOZELLI, R.L., 2014. Correlates of zooplankton beta diversity in tropical lake systems. PLoS One, vol. 9, no. 10, pp. e109581. http://dx.doi.org/10.1371/journal. pone.0109581. PMid:25330034.

LORENZI, H., 2000. Plantas daninhas do Brasil: terrestres, aquáticas, parasitas e tóxicas. Nova Odessa: Instituto Plantarum. $279 \mathrm{p}$.

MACKERETH, F.J.H., HERON, J. and TALLING, J.F., 1978. Water chemistry: some revised methods for limnologists.
Cumbria: Freshwater Biological Association. 120 p. Scientific Publication, no. 36.

MARCONDES, D.A.S., MUSTAFÁ, A.L. and TANAKA, R.H., 2003. Estudo para o manejo integrado de plantas aquáticas no reservatório de Jupiá. In: S.M. THOMAZ and L.M. BINI, eds. Ecologia e manejo de macrófitas aquáticas. Maringá: EDUEM, pp. 299-317.

MARTINS, D., COSTA, N.V., TERRA, M.A. and MARCHI, S.R., 2008. Caracterização da comunidade de plantas aquáticas de dezoito reservatórios pertencentes a cinco bacias hidrográficas do estado de São Paulo. Planta daninha, vol. 26, no. 1, pp. 17-32.

NAHLIK, A.M. and MITSCH, W.J., 2006. Tropical treatment wetlands dominated by free-floating macrophytes for water quality improvement in Costa Rica. Ecological Engineering, vol. 28, no. 3, pp. 246-257. http://dx.doi.org/10.1016/j.ecoleng.2006.07.006.

NEIFF, J.J. 2001. Diversity in some tropical wetland systems of South America. In: B. GOPAL, W.J. JUNK, and J.A. DAVIS, eds. Biodiversity in wetlands: assessment, function and conservation. Leiden: Backhuys Publishers, pp. 157-186.

NEIFF, J.J., CASCO, S.L. and POI DE NEIFF, A., 2008. Response of Eichhornia crassipes (Pontederiaceae) to water level fluctuations in two lakes with different connectivity in the Paraná River floodplain. Revista de Biologia Tropical, vol. 56, no. 2, pp. 613-623. PMid:19256432.

NEVES, G.P., 2008. Efeitos do tempo de residência, morfometria e estado trófico sobre as assembléias de microcrustáceos (Cladocera e Copepoda) dos reservatórios de Chavantes e Salto Grande (rio Paranapanema, SP/PR). Botucatu: UNESP-IB, 250 p. Dissertação de Mestrado em Zoologia.

NOGUEIRA, M.G., 2005. Limnologia de reservatórios e sistemas em cascata. In: F. ROLAND, D. CESAR and M. MARINHO, eds. Lições de limnologia. São Carlos: Rima, pp. 141-160.

NOTARE, M., 1992. Plantas hidrófilas e seu cultivo em aquário. Rio de Janeiro: Ed. Sudamérica. 238 p.

ORLOB, G.T., ROESNER, L.A. and NORTON, W.R., 1969. Mathematical models for prediction of thermal energy changes in impoundments. Washington, D.C.: US Environmental Protection Agency. FWQA Report, no. 16130EXT12/69.

PARTANEN, S., LUOTO, M. and HELLSTEN, S., 2009. Habitat level determinants of emergent macrophyte occurrence, extension and change in two large boreal lakes in Finland. Aquatic Botany, vol. 90, no. 3, pp. 261-268. http://dx.doi.org/10.1016/j. aquabot.2008.11.001

PIEDADE, M.T.F., JUNK, W., D ÂNGELO, S.A., WITTMANN, F., SCHÖNGART, J., BARBOSA, K.M.N. and LOPES, A., 2010. Aquatic herbacious plants of the Amazon floodplains: state of art and research needed. Acta Limnologica Brasiliensia, vol. 22, no. 2 , pp. 165-178. http://dx.doi.org/10.4322/actalb.02202006.

POMPÊO, M.L.M., HENRY, R. and MOSCHINI-CARLOS, V., 2001. The water level influence on biomass of Echinochloa polystachya (PAOACEAE) in the Jurumirim Reservoir (São Paulo, Brazil). Revista Brasileira de Biologia. Brazilian Journal of Biology = Revista Brasileira de Biologia, vol. 61, no. 1, pp. 19-26. http://dx.doi.org/10.1590/S0034-71082001000100004.

POTT, V.J. and POTT, A., 2000. Plantas aquáticas do Pantanal. Brasília: Embrapa. 404 p

RIEMER, D.N., 1984. Introduction to freshwater vegetation. Westport: AVI Publishing Co. Inc. 207 p. 
ROLON, A.S., HOMEM, H.F. and MALTCHIK, L., 2010. Aquatic macrophytes in natural and managed wetlands of Rio Grande do Sul State, Southern Brazil. Acta Limnologica Brasiliensia, vol. 22, no. 2, pp. 133-146. http://dx.doi.org/10.1590/S2179975X2010000200003.

SANTAMARIA, L., 2002. Why are most aquatic plants widely distributed? Dispersal, clonal growth and small-scale heterogeneity in stressful environment. Acta Oecologica, vol. 23, no. 3, pp. 137-154. http://dx.doi.org/10.1016/S1146-609X(02)01146-3.

SCREMIN-DIAS, E., POTT, V.J., HORA, R.C. and SOUZA, P.R., 1999. Nos jardins submersos da Bodoquena - Guia para identificação de plantas aquáticas de Bonito e região. Campo Grande: Editora UFMS. 160 p.

SCULTHORPE, C.D., 1967. The biology of aquatic vascular plants. London: Edward Arnold. 609 p.

SISTEMA DE INFORMAÇÕES PARA O GERENCIAMENTO DE RECURSOS HÍDRICOS DO ESTADO DE SÃO PAULO - SIGRH, 2008 [viewed 17 October 2014]. São Paulo: SIGRH. Available from: http://www.sigrh.sp.gov.br/cgi-bin/sigrh_index.exe

STRAŠKRABA, M., 1999. Retention time as a key variable of reservoir limnology. In: J.G. TUNDISI and M. STRAŠKRABA, eds. Theoretical reservoir ecology and its applications. Leiden: Brazilian Academy of Science, pp. 385-410.

TANAKA, R.H., CARDOSO, L.R., MARTINS, D., MARCONDES, D.A.S. and MUSTAFÁ, A.L., 2002. Ocorrência de plantas aquáticas nos reservatórios da Companhia Energética de São Paulo. Planta daninha, vol. 20, pp. 101-111.

THOMAZ, S.M. and CUNHA, E.R., 2010. The role of macrophytes in habitat structuring in aquatic ecosystems: methods of measurement, causes and consequences on animal assemblages'compositi0on and biodiversity. Acta Limnologica Brasiliensia, vol. 22, no. 2, pp. 218-236. http://dx.doi.org/10.4322/actalb.02202011.
THOMAZ, S.M., CARVALHO, P., MORMUL, R.P., FERREIRA, F.A., SILVEIRA, M.J. and MICHELAN, T.S., 2009a. Temporal trends and effects of diversity on occurrence of exotic macrophytes in a large reservoir. Acta Oecologica, vol. 35, no. 5, pp. 614-620. http://dx.doi.org/10.1016/j.actao.2009.05.008.

THOMAZ, S.M., CARVALHO, P., PADIAL, A.A. and KOBAYASHI, J.T., 2009b. Temporal and spatial patterns of aquatic macrophyte diversity in the Upper Paraná River floodplain. Brazilian Journal of Biology = Revista Brasileira de Biologia, vol. 69, no. 2, (suppl.), pp. 617-625. http://dx.doi.org/10.1590/S1519-69842009000300016. PMid:19738968.

THOMAZ, S.M., PAGIORO, T.A., BINI, L.M. and MURPHY, K.J., 2006. Effect of reservoir drawdown on biomass of three species of aquatic macrophytes in a large sub-tropical reservoir (Itaipu, Brazil). Hydrobiologia, vol. 570, no. 1, pp. 53-59. http:// dx.doi.org/10.1007/s10750-006-0161-9.

VESTERGAARD, O. and SAND-JENSEN, K., 2000. Alkalinity and trophic state regulate aquatic plant distribution in Danish lakes. Aquatic Botany, vol. 67, no. 2, pp. 85-107. http://dx.doi. org/10.1016/S0304-3770(00)00086-3.

VILARRUBIA, T.V. and COVA, M., 1993. Estudio sobre la distribución y ecología de macrófitos acuáticos en el embalse de Guri. Interciencia, vol. 18, no. 2, pp. 77-82.

VOLLENWEIDER, R.A., 1968. Scientific fundamentals of the eutrophication of lakes and flowing waters, with particular reference to nitrogen and phosphorous as factors in eutrophication. Paris: Organization for Economic Cooperation and Development. 192 p. DAS/CSI/68.27.

WERSAL, R.M. and MADSEN, J.D., 2011. Influences of water column nutrient loading on growth characteristics of the invasive aquatic macrophyte Myriophyllum aquaticum (Vell.) Verdc. Hydrobiologia, vol. 665, no. 1, pp. 93-105. http://dx.doi. org/10.1007/s10750-011-0607-6. 